\title{
PETERNAKAN BABI BERBASIS ZERO WASTE
}

\author{
Redempta Wea ${ }^{1 *}$, Andy Yumima Ninu ${ }^{1}$, Bernadete Barek Koten ${ }^{1}$ \\ ${ }^{1}$ Jurusan Peternakan, Politeknik Pertanian Negeri Kupang, Kupang \\ *Penulis Korespondensi: wearedempta@yahoo.co.id
}

\begin{abstract}
Abstrak
Pemeliharaan ternak babi pada kelompok Watu Kusa dan Het Fen tidak memperhatikan limbah sehingga menyebabkan polusi. Oleh karena itu dimanfaatkan dengan teknologi biogas. Tujuan kegiatan adalah menangani limbah ternak babi guna mengatasi pencemaran lingkungan sekaligus meningkatan kesadaran dan ketrampilan masyarakat dan penyelesaian masalah ekonomi dari segi pemanfaatan limbah sebagai biogas. Metode kegiatan yakni penyuluhan, demplot, dan pendampingan. Hasil kegiatan adalah melakukan instalasi biogas, penyuluhan manajemen pemelihaaan ternak dan pemanfaatn feces sebagai pupuk, demplot pengisian digester dan pembukaan lahan untuk penanaman sayuran dan rumput, dan pendampingan pemanfaatan sludge. Kesimpulannya kegiatan menghasilkan keuntungan berupa pemanfaatan feces menjadi biogas, mengurangi dampak polusi, meningkatkan pemanfaatan lahan, dan menghasilkan keuntungan serta diharapkan akan mendorong peran pemerintah dalam optimalisasi teknologi zero waste pada peternak babi dan hewani lainnya di NTT.
\end{abstract}

Kata kunci: Babi, Biogas, Demplot, Feces

\begin{abstract}
The maintenance of pigs in the Watu Kusa and Het Fen groups does not pay attention to the waste causing pollution. Therefore it is utilized with biogas technology. The objective of the activity is to handle pig livestock waste in order to overcome environmental pollution as well as to increase community awareness and skills and solve economic problems in terms of waste utilization as biogas. Method of activity that is counseling, demplot, and mentoring. The result of the activity is to install biogas, counseling the management of livestock maintenance and stool utilization as fertilizer, demplot filling digester and clearing land for vegetable and grass planting, and sludge utilization assistance. In conclusion, the activities resulted in the advantages of using feces into biogas, reducing the impact of pollution, increasing land use, and generating profits and expected to encourage the government's role in optimizing zero waste technology in other pig and animal breeders in NTT.
\end{abstract}

Keywords: Pig, Biogas, demonstration Plots, Waste

\section{PENDAHULUAN}

Peningkatan populasi masyarakat mempengaruhi peningkatan kebutuhan akan protein hewani. Peningkatan kebutuhan ini akan mempengaruhi jumlah populasi ternak yang semakin meningkat pula yang akan berdampak pada peningkatan jumlah limbah ternak berupa feces. Hal ini juga terjadi di daerah Nusa Tenggara Timur (NTT) yang dikenal sebagai daerah atau provinsi gudang ternak. Salah satu komoditi ternak yang banyak dipelihara oleh masyarakat NTT selain ternak sapi adalah ternak babi.

Komoditi ternak babi banyak dipelihara dikarenakan secara sosial budaya masyarakat NTT sudah memelihara dan memanfaatakan ternak babi dalam berbagai kehidupannya terutama dalam upacara adat serta sebagai status social masyarakat. Selain itu peningkatan pemelhraan yang memepengaruhi peningkatan populasi ternak babi juga dikarenakan semakin banyaknya wisata kuliner di NTT yang menyajikan olahan daging babi. Dikatakan demikian karena hingga kini terdapat 18 rumah makan dan restoran yang menyajikan kuliner khas NTT berupa Se'I Babi (http://kupang.tribunnews.com/2015/06/22/sei-babiikon-kuliner-di-kupang).

Pertumbuhan populasi ternak babi di Indonesia sejak tahun 2014 (7.694.130 ekor) hingga tahun 2015 (8.043.790 ekor) sebesar 4,54\% menempati urutan kedua setelah ternak sapi (Direktorat Jenderal Peternakan dan Kesehatan Hewan, 2015). Demikian halnya populasi ternak babi di NTT meningkat dari 1.500 .000 ternak babi di tahun 2013 meningkat menjadi 1.739 .000 ekor ternak babi di tahun 2014 (http://kupang.tribunnews.com/2014/02/25/babidominasi-peternakan-di-ntt).

Berdasarkan jumlah populasi ternak babi tersebut maka sesuai pernyataan Kruger et al., (1995) dalam Imbeah (1998) bahwa kotoran segar (feces) 
yang dihasilkan ternak babi setiap hari setara dengan $6 \%$ berat badan, maka jika diasumsikan rata-rata berat badan ternak babi $\pm 60 \mathrm{~kg}$ per ekor maka akan dihasilkan $\pm 3,6 \mathrm{~kg}$ feces segar per ekor per hari dan $\pm 2.203 .660 .800 \mathrm{~kg}$ feces segar per tahun di NTT. Jumlah limbah ternak babi yang banyak ini jika dikelola dengan baik merupakan potensi yang sangat besar untuk dimanfaatkan sebagai sumber penghasilan (biogas sumber bahan bakar, pupuk padat dan pupuk cair sebagai bahan pengolah lahan dan penyubur tanaman yang dapat dikonsumsi dan dijual, limbah hijauan sebagai hasil akhir pemupukan lahan dan tanaman dapat diberikan lagi pada ternak) sekaligus sebagai upaya menjaga agar tidak terjadi polusi lingkungan.

Menurut Firdaus (2009), peternakan babi memiliki potensi pencemaran lingkungan udara dan air. Sumber pencemar/kegiatan penyebab pencemaran lingkungan dalam usaha peternakan babi adalah berupa kotoran (feses dan urine), ceceran pakan dan minum babi, dan air cucian. Peternakan babi adalah mata rantai dalam rantai produksi daging babi dengan dampak lingkungan yang paling besar yang berkaitan dengan pemanasan global, eutrofikasi, dan peningkatan keasaman.

Kenyataan ini memberikan gambaran bahwa jika peternakan khususnya peternakan babi jika tidak dikelola dengan manajemen yang baik terutama manajemen limbah ternak maka akan menyebakan polusi dan masalah bagi lingkungan sekitarnya. Namun, jika limbah ini dapat dikelola dengan baik maka sangat berpontensi untuk mendatangkan keuntungan sekaligus mencegah pencemaran lingkungan dan pemanasaan global.

Pengolahan limbah ternak babi yang tidak maksimal ini terjadi juga di Dusun Oehau RT 23 RW 06 Desa Noelbaki Kecamatan Kupang Tengah, Kabupaten Kupang yang berjarak $18 \mathrm{Km}$ dari pusat kota dan berjarak $4 \mathrm{~km}$ dari institusi pengusul. Pada daerah ini terdapat peternak babi yang terhimpun dalam kelompok yakni kelompok Watu Kusa dan kelompok Het Fen. Lokasi mitra merupakan lokasi yang memiliki tekstur tanah liat dengan tingkat kemiringan yang cukup. Hal inilah yang menimbulkan masalah yang meresahkan masyarakat sekitar jika terjadi turunnya hujan maka limbah yang tidak dikelola dengan baik akan mengalir ke daerah di bawahnya yang menyebabkan polusi serta jenis tanah liat menyebabkan peresapan air yang tidak sempurna.

Kelompok Watukusa yang artinya batu besar yang melambnagkan kegigihan peternak dalam berusaha ternak babi dan beranggotakan 4 orang dengan ketua kelompok Ibu Aty Bete merupakan kelompok yang memelihara ternak babi dengan sistem perkandangan ynag baik, yang ditandai dengan kandang sudah dibuat dari bahan tembok, kemiringan lantai telah diperhatikan, jumlah pemeliharaan lebih dari 10 ekor, pakan sudah disusun sesuai standar kebutuhan ternak bahkan ada yang sudah memberikan pakan komplit, namun penanganan limbah tidak dilakukan dengan baik.
Dikatakan demikian karena limbah dari kandang dibiarkan saja mengalir ke tempat yang lebih rendah tanpa penanganan lebih lanjut dan bahkan ada yang membuang limbah di dalam lubang pembuangan tanpa penutup. Hal ini menimbulkan polusi bau dan lalat serta dapat mencemari lingkungan mengingat peternakan berada di daerah kemiringan sehingga air mudah mengalir ke tempat yang lebih rendah dan jika terjadi hujan maka air akan mudah membawa limbah ke semua tempat yang lebih rendah dan menyebabkan polusi lingkungan.

Hal yang sama terjadi juga di kelompok Het Fen yang artinya sesuatu yang baru mulai dibangun dimana pemeliharaan ternak umumnya hanya 1-3 ekor saja untuk memenuhi kebutuhan hidup pada saat tertentu jika membutuhkan dana cepat. Anggota kelompok berjumlah 4 orang peternak babi dengan ketua kelompok Ibu Lery. Namun pemeliharaan ternak di kelompok ini masih dilakukan secara sederhana dibanding kelompok Watu Kusa. Dikatakan demikian karena umumnya anggota kelompok memelihara ternak dalam kandang yang seadanya dengan tidak memperhatikan kemiringan lantai kandang, pakan diberikan seadanya untuk memenuhi kebutuhan hidup ternak babi dan umumnya memanfaatkan limbah dapur serta limbah feces dibiarkan seadanya tanpa penanganan yang baik. Hal ini terjadi karena pengetahuan tentang pemeliharaan ternak dan penanganan limbah yang baik tidak diketahui. Dikatakan demikian karena berdasarkan hasil wawancara diketahui bahwa beberapa peternak yang tidak membuat tempat penampungan limbah misalnya dengan menggali lubang karena alasan ekonomi dan kekuatiran jika lubang tersebut penuh maka mereka harus mengeluarkan lagi sedikit uang untuk menggali lubang yang sama di tempat lain sedangkan luasan tempat tinggal sempit.

Selain itu, secara sosial budaya beternak babi tidak dapat dipisahkan dari masyarakat NTT khususnya mitra karena ternak babi selalu digunakan dalam setiap acara adat dan dapat digunakan sewaktu-waktu untuk dijual terutama untuk kepentingan persekolahan anak. Hal ini dilakukan karena anggota kelompok mitra umumnya adalah kaum perempuan dengan sumber daya manusia yang terbatas dan menggantungkan hidupnya hanya dari penghasilan suami yang umumnya bekerja sebagai seorang wiraswasta yakni sebagai tukang, ojek, penggali sumur, dan pemukul batu dengan penghasilan yang tidak menentu.

Hal lain yang mendorong agar penanganan limbah dilakukan adalah masyarakat sekitar mitra merupakan masyarakat heterogen dengan kepercayaan yang berbeda khususnya masyarakat yang memeluk agama muslim yang dapat menimbulkan konflik yang tidak diinginkan serta lokasi mitra yang merupakan daerah lahan kering maka masyarakat hanya menggantungkan hidup dan sumber penghasilan mereka pada ternak babi yang dapat dijual sewaktu-waktu dan melakukan pertanian dengan sistem pertanaman ladang dan hanya 
menunggu turunnya hujan. Kenyataan ini diperparah lagi dengan sumber air yang minim dan terbatas.

Ketersediaan air yang minim ini mengakibatkan masyarakat sangat membutuhkan ketersediaan air bersih bagi pemenuhan kebutuhan hidup sehari-hari maupun untuk lahan pertanian maupun tumbuhan yang tidak mudah untuk bertumbuh. Sehingga untuk kebutuhan sehari-hari mitra tidak dapat mengambil tanaman hutan untuk dijadikan sebagai sumber bahan bakar melainkan menggantungkan hidupnya dengan cara membeli minyak tanah sebagai sumber bahan bakar. Demikian halnya maka pemeliharaan ternak babi harus dilakukan dengan baik agar tidak terjadi pencemaran pada lokasi sekitar terutama pada sumber air bersih serta pemanfaatan limbah yang baik dapat dijadikan sebagai sumber bahan bakar pengganti kayu bakar dan minyak tanah.

Lokasi mitra sekalipun dekat dengan institusi pengusul maupun dengan Kota Kupang, namun informasi mengenai cara pemeliharaan ternak babi yang baik hingga penanggulangan terhadap berbagai jenis penyakit ternak yang terjadi tidak menyentuh masyarakat sehingga pemeliharaan ternak babi dilakukan seadanya. Kompleksnya permasalahan mitra yang berujung dengan persoalan ekonomi maka berdasarkan hasil diskusi yang dilakukan disepakati dilakukan pengolahan limbah ternak babi dengan baik dengan menerapkan suatu manajemen yang dikenal dengan manajemen zero waste, yang merupakan suatu tindakan atau kegiatan yang memanfaatkan limbah ternak babi secara maksimal hingga limbah tersebut benar-benar tidak tersedia lagi atau dapat dimanfaatkan secara keseluruhan. Tujuan pelaksanaan program Iptek Berbasis Masyarakat (IbM) berbasis zero waste adalah penanganan limbah ternak babi secara menyeluruh guna mengatasi pencemaran lingkungan sekaligus meningkatan kesadaran dan ketrampilan masyarakat dan penyelesaian masalah ekonomi dari segi pemanfaatan limbah sebagai biogas.

\section{BAHAN DAN METODE}

Permasalahan prioritas mitra berupa tidak adanya penanganan limbah ternak yang baik yang mengakibatkan terjadinya polusi serta beberapa masalah lain yang terjadi dapat ditanggulangi dengan menyelesaikan permasalah limbah tersebut. Oleh karena itu beberapa tahapan atau langkah-langkah yang ditempuh adalah, sebagai berikut:

1. Melakukan survey ulang terhadap lokasi mitra yang sudah dilakukan pada saat penulisan proposal

2. Sebelum pelaksanaan kegiatan pengusul membagikan kuisioner pada masyarakat sekitar peternak guna mengetahui sikap atau respon masyarakat tentang pemeliharaan ternak babi yang dilakukan (bertujuan mendapatkan data dasar agar dapat mengukur dampak kegiatan IbM yang dilakukan)

3. Melakukan surat-menyurat pada pemerintah setempat baik tingkat RT/RW maupun Desa dengan tujuan prinsip dasar pengolahan limbah dapat dilihat oleh pemerintah setempat dan menularkan kepada masyarakat lain dalam bentuk kebijakan desa atau RT/RW

4. Melakukan penyuratan kepada lokasi mitra (ketua kelompok) terhadap kegiatan yang akan dilakukan sekaligus berdiskusi tentang waktu dan tempat yang akan digunakan untuk pelaksanaan penyuluhan maupun demplot pembuatan unit biogas, pemupukan, dan pembukaan lahan contoh untuk penanaman sayuran dan hijauan makanan ternak.

5. Mendatangi lokasi mitra sesuai kesepakatan dan berdiskusi dengan ketua dan anggota kelompok tentang pelaksanaan pembangunan unit biogas yang harus dilakukan bersama sebelum dilakukan penyuluhan.

6. Melaksanaan pembangunan unit biogas yang dilakukan secara bersama-sama (melibatkan tim, semua anggota kelompok mitra dan keluarga, dan mahasiswa)

7. Melaksanakan kegiatan pembukaan lahan baru sebagai lahan contoh untuk pemanfaatan sludge atau limbah biogas

8. Pembuatan pupuk padat/kompos dan pupuk cair dari sludge biogas

9. Mengadakan penyuratan ke pemerintah setempat tentang pelaksanaan penyuluhan sekaligus membuka pelaksanaan kegiatan IbM secara resmi (memberikan kesempatan juga kepada masyarakat lain yang ingin hadir)

10. Penanaman sayuran dan hijauan di lahan contoh sekaligus mengadakan kegiatan penyuluhan tentang materi (menggunakan leaflet dan brosur) yang telah disepakati bersama serta melaksanakan penyalaan kompor biogas perdana

11. Melaksanaan pemantauan terhadap penggunaan sludge biogas dan pertumbuhan sayuran dan hijauan makanan ternak

12. Melaksanaan pemanenan terhadap sayuran dan hijauan jika telah sampai umur panen dan memberikan pada ternak babi dan kambing juga untuk konsumsi mitra (sayuran) serta mengajarkan cara pengolahan jerami (amoniase jerami) untuk pakan ternak kambing dan meramu pakan ternak babi dari limbah sayuran dan limbah dapur

13. Membuat perhitungan ekonomi nilai manfaat dari kegiatan yang dilakukan secara sederhana agar dapat diketahui dampak sebelum dan sesudah pelaksanaan kegiatan terhadap lingkungan sosial budaya, ekonomi terutama gizi masyarakat, kesuburan tanah dan tanaman serta terhadap performans ternak yang dipelihara.

14. Setiap tahap kegiatan akan dilakukan pencatatan baik waktu, jenis kegiatan, dan dana yang dikeluarkan agar dapat dipertanggungjawabkan dengan baik serta dilakukan evaluasi pada setiap tahap kegiatan 
15. Setelah selesai kegiatan inti maka setiap dua minggu sekali tim melakukan pemantauan dan pembinaan atau pendampingan terhadap mitra sekaligus membuka diri berdiskusi terhadap segala masalah yang dihadapi mitra sesuai kompetensi tim.

16. Melaksanakan pembuatan pelaporan dan target luaran lainnya seperti yang telah direncanakan yang dilengkapi dengan dokumentasi kegiatan

17. Berdasarkan laporan kegiatan yang telah disusun tersebut kemudian akan dijadikan sebuah artikel pengabdian yang akan dipubliksikan dalam jurnal pengabdian nasional dan sebagai draf bahan ajar matakuliah produksi ternak babi.

\section{Metode pendekatan}

Metode pendekatan yang akan dilakukan sesuai dengan beberapa tahapan kegiatan yang dilakukan tersebut terdiri dari tiga tahap yakni melaksanakan penyuluhan atau penyadaran, pelaksanaan demplot, dan pendampingan. Kegiatan ini akan selalu didahului dengan melakukan pendekatan dan diskusi dengan anggota mitra. Beberapa metode pendekatan yang dilakukan tersebut digunakan untuk mengatasi masalah prioritas mitra sekaligus dapat menyelesaikan beberapa masalah mitra lainnya sesuai penjabaran diatas dengan harapan kehidupan social budaya dan keagamaan antara masyarakat mitra dan masyarakat lainnya tetap terpelihara dengan baik. Gambaran teknologi zero waste peternakan babi (pendekatan biogas) yang diterapkan disajikan pada Gambar 1. adalah, sebagai berikut:

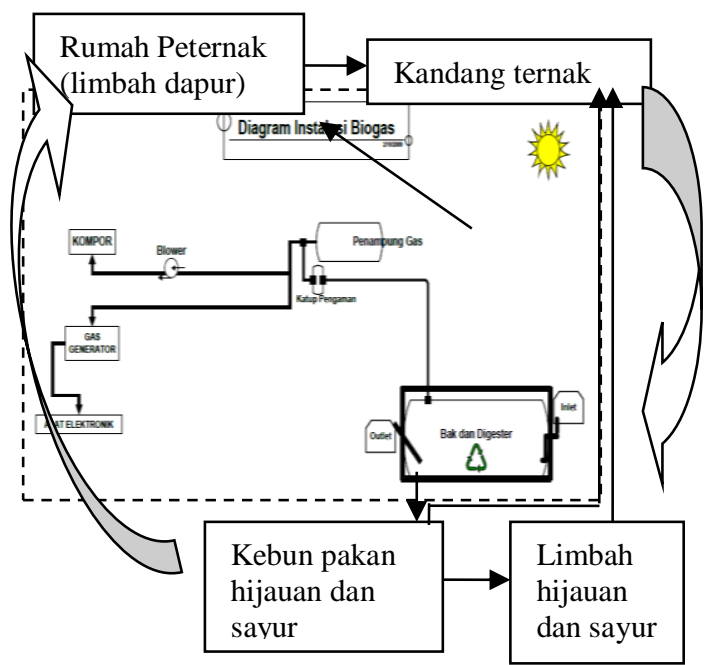

Gambar 1. Gambaran teknologi zero waste

\section{Prosedur Kerja}

Prosedur kerja yang dilakukan dalam merealisasikan tiga metode tersebut adalah:

1. Sebelum pelaksanaan kegiatan tim IbM melakukan pendekatan dengan mitra dan pemerintah setempat tentang lokasi pelaksanaan

2. Pengusul bersama mitra mendiskusikan tiga metode pendekatan yang akan dilakukan
3. Pengusul menyiapkan bahan yang akan disuluhkan tentang manajemen pemeliharaan ternak babi yang baik dari segi bibit, pakan, perkandangan, dan cara penanganan limbah yang baik serta dampak limbah jika tidak ditangani dengan baik.

4. Berdiskusi bersama tentang waktu penyuluhan dengan mitra, pemerintah setempat, dan masyarakat sekitar pemelihara ternak babi

5. Sesaat sebelum penyuluhan, pengusul membagikan kuisioner pada mitra dan masyarakat sekitar yang mengikuti kegiatan guna mengetahui sikap atau respon masyarakat tentang pemeliharaan ternak babi yang dilakukan (bertujuan mendapatkan data dasar agar dapat mengukur dampak kegiatan IbM yang dilakukan)

6. Penyuluhan dilakukan dengan menggunakan alat bantu berupa leaflet materi penyuluhan serta penjelasan tentang manajemen pemeliharaan, pemanafaatan limbah menjadi biogas, pemanfataan sludge menjadi pupuk, penjelasan ekonomi sederhana tentang manfaat kegiatan

7. Demplot bersama mitra tentang pencampuran feces dan air dengan perbandingan 1:1 kemudian melakukan pengisian ke dalam digester serta penggunaan sludge biogas menjadi pupuk cair dan padat yang ditebarkan pada lahan yang sebelumnya telah disiapkan

8. Melakukan pemantauan pemanenan sayuran dan hijauan yang ditanam menggunaan pupuk dari sludge biogas

9. Proses pendampingan dilakukan setiap dua minggu sekali dengan cara selalu melakukan survey terhadap pengisian feces ke dalam digester serta mengecek penggunaan gasnya serta berdiskusi tentang masalah lain seputar ternak babi berdasarkan pengetahuan dan pengalaman pengusul.

\section{HASIL DAN PEMBAHASAN}

Hasil pelaksanaan kegiatan yang dicapai dibagi dalam dua hal yakni hasil dan luaran yang dicapai, sebagai berikut:

\section{Hasil Kegiatan yang Dicapai}

Berdasarkan metode kegiatan dan prosedur kerja yang direncanakan maka hasil kegiatan yang dilakukan adalah:

1. Metode Penyuluhan dan Demplot:

Sebelum pelaksanaan kegiatan, tim melakukan survey dan pendekatan ulang pada mitra dengan mempertemukan mitra dengan ketua tim dan anggota kelompok yang diwakili oleh 2 anggota kelompok masing-masing. Pada saat pertemuan diputuskan secara aklamasi bahwa penempatan unit biogas akan dilaksanakan pada dua tempat yakni di lokasi ternak babi ibu Ketua Kelompok Watu Kusa dan ibu ketua kelompok Het Fen. Alasan pemilihan lokasi adalah jumlah ternak yang dipelihara lebih banyak $( \pm 20$ ekor induk) 
dibanding anggota lainnya yang hanya 2-3 ekor saja. Disamping itu pemilihan ini juga untuk mewakili sistem pemeliharaan tradisional dan modern (berdasarkan kualitas pakan dan perkandangannya).

Tim kemudian melakukan pendekatan terhadap pemerintah setempat dalam hal ini ketua RT dan Bapak Dusun Oehau. Selanjutnya, tim melakukan pemesanan unit biogas yang berasal dari kota kupang sendiri (unit biogas yang direncanakan dipesan dari Jember tidak jadi dilaksanakan karena alasan komunikasi dan transportasi). Unit biogas yang dipesan berjumlah dua unit yang kemudian diantar ke lokasi. Sebelum pengantaran unit biogas, sebelumnya dilakukan persiapan lubang digester yang dilakukan bersama serta pembuatan tempat inlet dan outlet untuk tempat masuk feces dan keluarnya sludge dari digester.

Pengisian awal digester menggunakan feces sapi segar karena saluran pembuangan dari kandang babi masih dalam pengerjaan guna penyesuaian dengan wadah pencampur inlet ke digester. Feces sapi yang dgunakan berasal dari satu tempat pemeliharaan sapi yakni PT Bumi Tirta yang berjarak $\pm 22 \mathrm{~km}$ dari lokasi mitra dengan tujuan agar proses fermentasi yang terjadi dalam digester berlangsung sama dan gas yang dihasilkanpun sama jumlah dan waktunya.

Digester yang digunakan merupakan digester yang terbuat dari fiber yang dimodifikasi dengan volume 1100 liter sedangkan alat penampung gas terbuat dari dua drum dengan ukuran yang berbeda serta kompor merupakan kompor gas yang telah dimodifkasi oleh pakar biogas Politani Negeri Kupang (Ir. Bernadus Ndoen, MP). Setelah semua unit biogas telah siap kemudian dilakukan pendekatan terhadap mitra dan anggota lainnya serta masyarakat sekitar yang tertarik untuk dilakukan kegiatan penyuluhan.

Kegiatan penyuluhan dilakukan dengan berlokasi di halaman rumah ketua Watukusa. Kegiatan penyuluhan melibatkan tiga orang nara sumber yang menjelaskan tentang sistem pemeliharaan ternak babi, pemanfaatan feces menjadi biogas dan pupuk, dan perhitungan ekonomis sederhana tentang pemanfaatan feces menjadi biogas dan pupuk dibandingkan jika dibiarkan terbuang.

Sebelum kegiatan didahului dengan doa kemudian dilanjutkan dengan penyuluhan. Setelah selesai penyuluhan kemudian dilanjutkan dengan demplot pemasangan instalasi biogas dan pencampuran feces bersama untuk dimasukkan ke dalam digester untuk dibiarkan mengalami fermentasi. Setelah itu makan bersama yang didahului dengan doa makan. Kegiatan penyuluhan kemudian ditutup dengan diskusi mengenai berbagai hal yang berkembang menyangkut ternak babi dengan diselingi makanan ringan serta ditutup dengan doa bersama.

Pada saat pelaksanaan penyuluhan dan demplot, peserta penyuluhan dan demplot sangat antusias. Hal ini ditandai dengan banyaknya masyarakat yang hadir selain anggota kelompok serta banyaknya pertanyaan seputar peternakan yang ditanyakan dan didiskusikan bersama.

Berdasarkan pengamatan diketahui bahwa proses fermentasi berlangsung dengan cepat. Dikatakan demikian karena dengan adanya proses fermentasi yang terjadi maka sludge pada hari kedua telah keluar karena adanya dorongan gas yang terbentuk. Sludge yang keluar tersebut kemudian dimanfaatkan sebagai pupuk baik pupuk padat maupun cair. Pupuk tersebut kemudian ditebar pada lahan yang sebelumnya telah digarap dan disiapkan untuk pananaman sayuran dan hijauan.

Pemanfaatan sludge biogas sebagai pupuk pada dua kelompok digunakan pada tanaman cabai dan buah naga (kelompok het Fen) dan pada tanaman kacang hijau dan rumput juga cabai (kelompok Watu Kusa). Berdasarkan pengamatan diketahui bahwa tanaman yang diberikan sludge biogas memberikan respon positf yang ditandai dengan perkembangan yang lebih cepat menghasilkan bunga dan buah. Hal ini sesuai pernyataan Wea et al. (2011) yang melakukan hal yang sama dengan menggunakan sludge biogas pada tanaman kacang panjang di daerah Fatukoa Kupang yang bertumbuh dan menghasilkan sulur dan buah lebih cepat serta banyak tunas baru yang muncul sehingga berdampak pada panen yang dapat dilakukan berulang-ulang.

\section{Metode Pendampingan:}

Kegiatan IbM terus dilakukan pada mitra dengan melakukan pendampingan dalam waktu dua kali seminggu. Pendampingan berupa pemantauan penggunaan unit biogas dengan penyaluran feces dari saluran pembuangan ke digester dengan terlebih bahulu melakukan pencampuran pada tempat pencampuran pada lubang inlet. Selain itu dilakukan pemantauan terhadap penggunaan sludge biogas sebagai pupuk serta pengamatan pertumbuhan tanaman juga pemantauan terhadap gas yang terbentuk.

\section{Partisipasi Mitra}

Berdasarkan prosedur kerja dan rencana kegiatan yang dilakukan tersebut diketahui bahwa dalam setiap tahap kegiatan dari awal hingga akhir baik diskusi, pelaksanaan kegiatan penyuluhan dan demplot serta kegiatan pendampingan selalu melibatkan peranan mitra secara aktif dan melakukan pendekatan dengan pemerintah setempat dalam hal ini ketua RT dan Bapak Dusun yang sangat antusias agar kegiatan ini dapat terlaksana dan sangat 
mengharapkan agar dapat dilakukan pada lokasi lainnya. Hal ini dikarenakan mitra kegiatan sebagai subyek pelaku dan penerima program kegiatan yang diharapkan akan menjadi contoh bagi masyarakat sekitar sehingga tidak terjadi lagi kesenggangan antara kalangan akademik, mitra, masyarakat sekitar, dan pemerintah setempat.

\section{Capaian Pelaksaaan Kegiatan}

Capaian Pelaksanaan kegiatan "IbM Zero Waste Peternakan Babi" sesuai target yang ditetapkan:

1. Peningkatan $100 \%$ pemanfaatan feces sebagai biogas.

Penempatan unit biogas yang dilakukan memberikan dampak yang signifikan dimana feces yang semula dibiarkan terbuang mengalir begitu saja pada tanah kosong (Kelompok Het Fen) dan pada tanah kosong dan lubang pembuangan (Kelompok Watu Kusa) menjadi terarah hanya pada satu lubang pembuangan yakni digester biogas.

2. Pengurangan $100 \%$ polusi bau yang disebabkan oleh feces.

Anstusian masyarakat meningkat ketika melakukan kunjungan lokasi ke kandang babi yang dilengkapi unit biogas dikarenakan tidak tercium bau feces. Hal ini dikarenakan feces yang masuk ke dalam digester mengalami proses fermentasi oleh mikroorganisme sehingga mikroorganisme pembusuk penimbul bau menjadi berkurang.

3. Terbentuknya biogas dengan kualitas yang berbeda (waktu terbentuk dan lama menyala kompor gas).

Biogas mulai terbentuk pada saat yang bersamaan yakni dua hari setelah pengisian yang ditandai dengan keluarnya sludge biogas dari lubang outlet digester. Hal ini dikarenakan pada saat pengisian menggunakan feces sapi yang berasal dari tempat pemeliharaan yang sama dengan perbandingan feces air yakni 1:1. Namun, terjadi perbedaan pembentukan gas dan lamanya penyalaan kompor gas antar dua unit biogas pada dua kelompok mitra. Hal ini dikarenakan terdapat perbedaan pemeliharaan terutama pemberian pakan yakni pada kelompok Het Fen pemberian pakanyang dilakukan tidak melalui perhitungan ransum yang baik yang ditandai dengan pemberian dedak yang berlebihan sedangkan pada kelompok Watu Kusa pemberian pakan sudah disusun dengan formulasi yang baik dan sesuai dengan kebutuhan fase hidup ternak babi. Perbedaan ini memberikan dampak terhadap feces yang dihasilkan dan kualitas biogas yang dihasilkan, yakni pada kelompok Het Fen dengan pengisian dalam waktu yang sama maka gas yang terbentuk membutuhkan waktu \pm 7 hari dan kompor hanya bertahan menyala \pm 8 menit sedangkan pada kelompok Watu Kusa sudah terbentuk \pm 5 hari serta lama waktu kompor menyala \pm 12 menit.

4. Peningkatan pemanfaatan lahan kosong. Kegiatan yang dilakukan memberikan keuntungan terhadap oenggunaan lahan. Dikatakan demikian karena lahan yang sebelumnya tidak termanfaatkan karena sebagai lahan penyalurn limbah kini dapat dibersihkan dan dimanfaatkan untuk penanaman sayuran dan hijauan. Selain itu lahan menjadi lebih tertata dengan baik. peningkatan pemanfaatan lahan ini pada kelompok Watu Kusa seluas $\pm 150 \mathrm{~m}^{2}$ dan kelompok Het Fen seluas $\pm 150 \mathrm{~m}^{2}$.

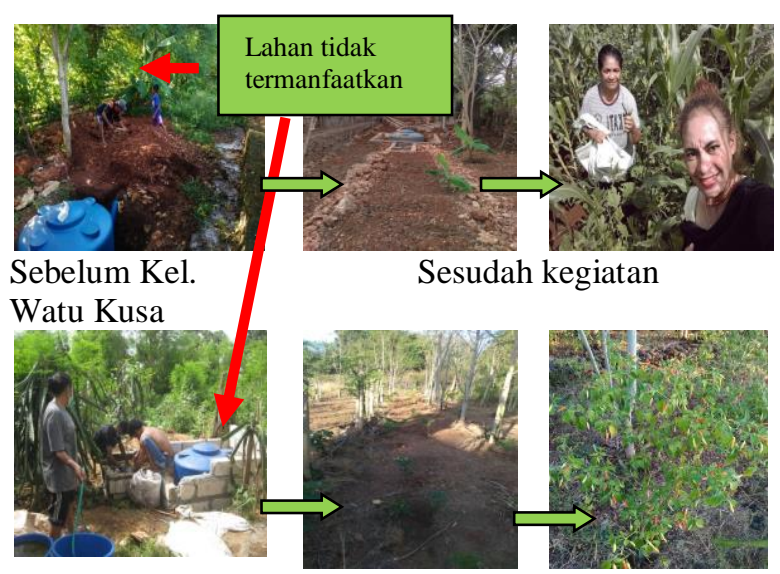

Sebelum Kel. Het Fen

5. Peningkatan penggunaan feces dan sludge biogas sebagai pupuk.

Feses yang terbuang dulu akhirnya dapat termanfaatakn secara menyeluh dengan adanaya penggunaan sludge biogas sebagai pupuk. Pupuk yang digunakan merupakan campuran pupuk cair dan padat.

6. Peningkatan pertumbuhan dan produksi sayuran dan hijauan.

Sludge biogas yang keluar dari outlet digester kemudian dimanfaatkan sebagai pupuk yakni pada kelompok Het Fen sebagai pupuk tanaman cabai, marungga, dan buah naga sedangkan pada kelompok Watu Kusa sebagai pupuk tanaman sayuran kacang hijau dan hijauan rumput. Berdasarkan pengamatan terlihat bahwa terjadi perbedaan pertumbuhan anatara tanaman yang diberi pupuk sludge dan yang tidak, yakni pertumbuhan tanaman yang diberi pupuk sludge lebih subur dana waktu mencapai fase berbunga dan berbuah lebih cepat. Hal ini berdampak pada waktu panen yang lebih singkat.

7. Peningkatan pengetahuan mitra dan masyarakat tentang pemeliharaan ternak dan pemanfaatan feces sebagai pupuk.

Pengetahuan mitra tentang pemeliharaan ternak terutama pemanfaatan feces sebagai pupuk dan biogas menjadi meningkat, yang diketahui dari kuisioner yang diisi sebelum pelaksanaan kegiatan dan jawaban antusias terhadap 
pertanyaan yang diajukan pada saat selesai kegiatan.

8. Peningkatan keakraban hubungan persaudaraan antara mitra dan masyarakat sekitar.

Hubungan antara mitra dan masyarakat sekitar bahkan peternak lain yang hadir pada saat itu semakin meningkat dibanding sebelumnya, yang ditandai mulai adanya guyonan yang dilontarkan dan tegur sapa setiap harinya.

9. Peningkatan penerimaan masyarakat sekitar terhadap pemeliharaan ternak babi

Kegiatan ini juga menghasilkan dampak yang baik terhadap penerimaan masyarakat sekitar terhadap pemeliharaan ternak babi dikarenakan tidak timbulnya lagi bau yang menyengat akibat aktivitas peternakan babi dalam jumlah banyak serta sudah adanya tempat penampungan limbah yang baik pada peternak lainnya.

10. Peningkatan ekonomi peternak (perhitungan sederhana)

Secara sederhana dapat dilakukan perhitungan sederhana bagi kedua kelompok yakni:

a. Kelompok Het Fen:

Lahan ditanami cabai dengan luasan $\pm 150 \mathrm{~m}^{2}$ dengan jarak tanam $50 \mathrm{~cm}$ x $50 \mathrm{~cm}$ maka dapat ditanam tanaman cabai sebanyak 300 titik tanam. Jika satu pohon cabai menghasilkan $\pm 300 \mathrm{~g}$ maka akan dihasilkan $90.000 \mathrm{~g}$ atau $90 \mathrm{~kg}$ tanaman cabai pada akhir bulan kelima, serta jika cabai dijual dengan harga Rp. 50.000/kg maka akan menghasilkan keuntungan sebesar Rp 4.500.000 atau Rp 500.000/bulan bagi peternak dibandingkan lahan dibiarkan untuk aliran feces dan air cucian kandang. Selain itu pemasukan dapat diperoleh dari tanaman marungga (1 ikat di pasaran dijual dengan harga Rp 2.000) dan buah naga.

b. Kelompok Watu Kusa:

Kelompok Watu Kusa memanfaatkan dengan menanam rumput dan kacang hijau. Lahan dibuat dalam 6 petak dan ditanami kacang hijau dengan jarak tanam $60 \mathrm{~cm} \mathrm{x}$ $100 \mathrm{~cm}$ dan rumput gajah dengan jarak tanam $1 \mathrm{~m}$ x $1 \mathrm{~m}$. Kacang hijau sudah dapat dipanen sejak umur 40 hari dan dipanen hingga tiga kali sedangkan rumput sudah berproduksi sejak dua bulan. Berdasarkan hasil yang diperoleh maka kacang hijau dipanen sebanyak $\pm 20 \mathrm{~kg}$ sedangkan rumput gajah dengan 1 petak terdapat 25 titik tanam maka terdapat 150 titik tanam. Satu titik tanam rumput gajah menghasilkan 7$10 \mathrm{~kg}$ rumput gajah. Rumput gajah dijual di pasaran dengan harga Rp 2000/kg maka diperoleh keuntungan 1050-1500 $\mathrm{kg}$ atau menghasilkan Rp 2.100.000 - 3.000.000. Demikian halnya kacang hijau dijual di pasaran dengan harga $\mathrm{Rp} 28.000 / \mathrm{kg}$ maka penghasilan yang diperoleh sebesar Rp 560.000. Jadi total keuntungan yang diperoleh peternak adalah Rp 2.660.000 -
Rp 3.560.000 selama \pm 3 bulan atau sebesar Rp 886.666 - Rp 1.186.666/bulan atau hijauannya diberikan pada ternak sapi untuk meningkatkan perfomans pertumbuhan sapi. Berdasarkan pelaksanaan kegiatan yang dihadiri oleh masyarakat sekitar dan pemerintah setempat selain anggota mitra serta pendampingan memberikan dampak baik dengan bertambahnya pemanfaatan feces sebagai pupuk organik tanaman oleh peternak di sekitar lokasi dan diharapkan akan diterapkan pada masing-masing usaha peternakan lainnya selain ternak babi sehingga tidak terjadi polusi serta adanya kebijakan yang diambil oleh pemerintah setempat tentang pemeliharaan ternak babi dan ternak lainnya pada lokasi lainnya.

\section{KESIMPULAN}

Berdasarkan hasil kegiatan, disimpulkan bahwa kegiatan ini menghasilkan keuntungan berupa pemanfaatan feces menjadi biogas, mengurangi dampak polusi tanah dan udara, meningkatkan pemanfaatan lahan dengan tanaman sayuran dan rumput, dan menghasilkan keuntungan serta diharapkan akan mendorong peran pemerintah dalam optimalisasi teknologi zero waste pada peternak babi dan hewani lainnya di NTT.

\section{UCAPAN TERIMA KASIH}

Ucapan terimakasih penulis sampaikan bagi Kemeristek Dikti atas pendanaan hibah pengabdian IbM, Direktur dan pimpinan UPM Politani Negeri Kupang, dan tim kegiatan serta mahasiswa atas semua partisipasi aktifnya.

\section{Daftar Pustaka}

Firdaus, (2009)., Pencemaran Lingkungan Oleh Peternakan Babi Dan Upaya Penanggulangannya. http://firdaustkubh.blogspot.co.id/2009/12/pen cemaran-lingkungan-oleh-peternakan.html. Diunduh tanggal 04 April 2016.

Imbeah, M., (1998). Composting Piggery Waste: A Review. Department of Animal Production, University of Queensland, Gatton College, Qld 4345, Australia

Pos Kupang, (2014). Pengembangan Ternak Sapi NTT, Babi Dominasi Peternakan di NTT. http://kupang.tribunnews.com/2014/02/25/bab i-dominasi-peternakan-di-ntt. Diunduh tanggal 04 April 2016.

Pos Kupang, (2015). Ekslusif Sei Babi di Kupang Sei Babi Ikon Kuliner di Kupang. http://kupang.tribunnews.com/2015/06/22/seibabi-ikon-kuliner-di-kupang. Diunduh tanggal 04 April 2016. 
Wea R., Koten B. B., dan Foenay T. A. Y., (2011). Pemanfaatan limbah ternak sapi sebagai bio gas. Buletin Perancangan dan kaji tindak Universitas Nusa Cendana Kupang. (26), 2124. 